Шульжук, Наталія. «Особливості лінгвістичного аналізу художнього тексту як прагматичнокомунікативної єдності». Лінгвостилістичні студії, вип. 10, 2019, с. 195-203.

Shulzhuk Natalia. "The Pecularities of the Linguistic Analysis of Literary Text as Pragmatic and Communicative Unity". Linguostylistic Studies, iss. 10, 2019, pp. 195-203.

удк 81'42

https://doi.org/10.29038/2413-0923-2019-10-203-211

\title{
ОСОБЛИВОСТІ ЛІНГВІСТИЧНОГО АНАЛІЗУ ХУДОЖНЬОГО ТЕКСТУ ЯК ПРАГМАТИЧНО-КОМУНІКАТИВНОЇ ЄДНОСТІ
}

\author{
Наталія Шульжук \\ Рівненський державний гуманітарний університет, \\ Рівне, Україна
}

У статті доведено, що художнє мовлення - це об’єкт лінгвістичних досліджень у контексті двох мовознавчих парадигм - традиційної (системоцентричної) та сучасної (прагматично-комунікативної). 3'ясовано, що дискурсивний статус художнього тексту актуалізує прагматичний чинник у ньому; це уможливлює його інтерпретацію не лише як фіксацію повідомлення в комунікативному акті, а й акцентує увагу на комунікативних ролях автора й читача, збіг концептуальних систем яких $\epsilon$ умовою для його адекватного розуміння.

Ключові слова: текст, художній дискурс, концепт, сприйняття й інтерпретація тексту, прагматично-комунікативна єдність, комунікативність, діалогічність, лінгвістичний аналіз тексту.

Shulzhuk Natalia. The Pecularities of the Linguistic Analysis of Literary Text as Pragmatic and Communicative Unity. The article substantiates modern paradigmatic space of linguistics, represented by the coexistence of two dominant paradigms - pragmatic and cognitive, and actualizes the text categories. The study argues that the distinction between them is determined by the dialogue interaction between the author and the reader through the artistic text. Due to this fact, the perspective of linguistic pragmatics and communicative linguistics in this area is the study of such aspects of the literary text as comprehension, perception and interpretation.

Artistic creativity is proved to be a complex communicative process that is the realization of a certain communicative intention of the author towards the recipient/addressee. In the course of the artistic text generation, the author models a communicative situation which is defined by both verbal and non-verbal factors. They affect the text creation as well as its comprehension which is the unifying link of the communicative space of the reader's interpretation and the communicative space of the author. However, the reader does not always interpret the pragmatic approach of the author adequately: his discursive activity actualizes the author's intentions, but the reader may also add his own ones.

The author of the article suggests using the term-concept of artistic discourse when referring to the literary text as a single communicative entity, in which the communicative intentions of the speaker are realized, taking into account the pragmatic approach to discourse analysis. Such an approach makes it possible to understand the artistic text as a pragmatic and communicative unity and interpret the content structure of the literary text in

(C) Шульжук Н., Східноєвропейський національний університет імені Лесі Українки, 2019.

Це стаття відкритого доступу на умовах CC BY-NC 4.0 
three dimensions - vertical, horizontal and going into depth. The latter concerns the implicit context, which often manifests the author`s intention.

In the polyparadigmatic space of modern linguistics, the anthropology-oriented theories, acquire special significance in the focus of which is a person who perceives and retransmits the language under specific socio-historical conditions. The author emphasizes that in the course of the linguistic analysis of the artistic text it is appropriate to actualize the definition of the "concept" as a formed idea in a person's mind about the components of the real and imaginary world, expressed by the linguistic units. The article proves that the search for the concept is related to the comprehension of the author's idea, interpretation of the content of the artistic text, representing the linguistic picture of the world of its author.

A dialogue in the literary dicourse can be expressed both at the level of inter-subjective interaction and the inter-text interaction.

The author is certain, that there are preconditions for studying language as an ethnic phenomenon. Therefore it is expedient to identify and study linguistic units in the structure of the artistic text to identify cultural and psychological characteristics of an ethnic group. The article convincingly proves that artistic speech is the object of linguistic research within two linguistic paradigms - the traditional (system-centered), focused on the study of linguistic units and the linguistic style of the artistic speech of individual authors, and modern (pragmatic and communicative), oriented to the communicative situation and its components. The discourse status of the artistic text actualizes the pragmatic factor in it, which makes it possible to interpret the artistic text as a fixation of the message in a communicative act and emphasizes the communicative roles of the author and the reader. It means that the artistic text is just one of the components of artistic communication, which, additionally, forms discourses of the author and the reader. The coincidence of their conceptual systems is a prerequisite for an adequate comprehension of the artistic text.

Key words: text, artistic discourse, concept, perception and interpretation of the text, pragmatic and communicative unity, communicative, dialogic, linguistic analysis of the text.

Вступ. Сучасні лінгвістичні дослідження зорієнтовані на вивчення функцій мовних одиниць у різних формах мовленнєвої діяльності, результативність якої демонструє таке комплексне явище, як текст, що здавна привертав увагу дослідників як особливий об`єкт вивчення. Проблеми тексту досліджували лінгвісти й психолінгвісти (Л. Булаховський, I. Гальперін, М. Жинкін, О. Леонтьєв, Т. Дрідзе, Ю. Лотман, Ф. Бацевич, О. Селіванова та ін.). Положення про те, що оволодіння лінгвістичною теорією тексту сприяє ефективному формуванню умінь текстотворення i текстосприйняття, доведено у працях Т. Ладиженської, В. Статівки. Текстотипологічні питання досліджували В. Виноградов, А. Новиков, Л. Якубинський та ін. Актуальною проблема тексту є і в лінгводидактиці (праці І. Дроздової, С. Єрмоленко, Л. Златів, В. Мельничайка, М. Пентилюк, Л. Федотової, Л. Шиянюк та ін.).

Сучасні дослідники інтерпретують текст як комплекс вербальних знаків природної мови, що характеризується не лише формальнозмістовою цілісністю, а й прагматично-комунікативною єдністю (Кондратенко). Н. Кондратенко, виокремлюючи домінантні лінгвістичні підходи до вивчення текстових явищ, крім логіко-граматичного, який зумовлює визначення таких категорій тексту, як інформативність, модальність, темпоральність, та психолінгвістичного, що зорієнтований 
передусім на процеси породження та сприйняття тексту, акцентує увагу на комунікативному, який зосереджує увагу дослідників на таких текстових категоріях, як комунікативність, інтерактивність, діалогічність, оскільки текст - компонент комунікативного акту. Схожа наукова позиція представлена у працях О. Воробйової, І. Колегаєвої, А. Папіної, О. Селіванової, Є. Сидорова. Ці та інші текстові категорії найповніше реалізуються у тканині художнього тексту, специфіка мови якого була предметом вивчення багатьох науковців.

Традиційно мову художніх творів кваліфікують як підсистему загальнонаціональної мови, основною ознакою якої $\epsilon$ образність. Н. Лисенко слушно зауважила, що художнє слово як матеріальний носій образності в літературі - явище поліфункційне: воно, крім комунікативної (спілкування між людьми (автор - читач), між народами і епохами) та загальномистецької функцій (пізнання об’єктивної дійсності), виконує ще й інші - естетичну (засіб передачі естетично значущої інформації), світоглядну (формує світоглядні орієнтири особистості), художньоконцептуальну (митець оцінює реалії і явища дійсності, концептуалізуючи їх у художньому висловлюванні), суспільну (засіб вираження суспільної свідомості), визначаючи певні ціннісні орієнтири (336).

Специфіка художньої літератури полягає в тому, що вона спрямована на естетичну трансформацію мовних засобів усіх рівнів для посилення їх зображально-виражальних характеристик, що уможливлює максимально повне відтворення художнього змісту, а також індивідуальноособистісного мовлення авторів художніх текстів.

У мовознавстві поняття «стиль» і «текст» взаємопов'язані. На думку С. Єрмоленко, «поняття тексту, текстової схеми, стосується стилю як цілісності, як певного динамічного явища, процесу...» (27). Зауважимо, що лінгвістика вивчає стиль з позиції мовних одиниць, літературознавство ж вияву мовленнєвої діяльності (художнього мислення). Інакше кажучи, стилістика художнього мовлення спрямована на вивчення естетичної вартості мовних одиниць в літературному творі та образу автора як його ідейно-композиційного стрижня, навколо якого організуються мовні засоби.

Художній текст є об'єктом вивчення лінгвістики тексту, стилістики, герменевтики, проте виявляти «систему співфункцій усіх мовних одиниць та їх категорій, що беруть участь у створенні системи образів у певному тексті» (Ковалик 12), покликаний передусім лінгвістичний аналіз тексту.

Традиційний підхід до лінгвістичного аналізу художнього тексту спрямований на його дослідження за граматичними і стилістичними параметрами, зосереджує увагу на його внутрішніх властивостях (текстових одиницях, граматичних категоріях, зв'язках і стилістичних засобах). Безумовно, вагомі результати, отримані в галузі граматики, стилістики та структури тексту, сприяють успішному здійсненню його лінгвоаналізу, проте сучасний парадигмальний простір мовознавства, 
представлений співіснуванням двох домінантних парадигм - прагматичної та когнітивної, актуалізує текстові категорії, виокремлення яких зумовлене діалогічною взаємодією автора з читачем через посередництво художнього тексту. Тому у контексті лінгвістичної прагматики та комунікативної лінгвістики перспективними у цій царині $є$ дослідження таких аспектів художнього тексту, як розуміння, сприйняття та інтерпретація.

Мета статті - з'ясувати особливості лінгвістичного аналізу художнього тексту як прагматично-комунікативної єдності.

Матеріал і методи дослідження. Аналіз літератури 3 теми дослідження засвідчив, що з-поміж традиційних дослідницьких підходів до лінгвістичного аналізу тексту більшість мовознавців акцентує увагу на лінгвоцентричному (передбачає вивчення окремих аспектів тексту синтаксису, семантики, структури та стилістики тексту), текстоцентричному (ґрунтується на тлумаченні тексту як структурносемантичної цілісності), антропоцентричному (пов'язаний 3 інтерпретацією тексту 3 позицій автора й читача) та когнітивному (тлумачення тексту як складного знака, що «виражає знання письменника про дійсність, реалізовані у формі індивідуально-авторської картини світу» (Бабенко, і Казарин 15)). Поділяючи думку Н. Кондратенко, вважаємо за доцільне якнайповніше застосування комунікативного (дискурсного) підходу, який уможливлює аналіз художнього тексту як компонента комунікативної взаємодії мовця (автора) та реципієнта (читача).

Результати дослідження та дискусія. Звернімо увагу на те, що чимало дослідників для найменування художнього тексту послуговується терміном «дискурс», оскільки «аналіз дискурсу перемикає увагу з тексту як такого на прагматичні моменти, що визначили ті або ті його особливості, без урахування яких неможлива його правильна інтерпретація» (Михайлов 8). Спробу довести дискурсивний статус художнього тексту здійснили Н. Кулібіна, Т. Плеханова, Ю. Прохоров та ін.

Лінгвісти пропонують визначення дискурсу і як процесу взаємодії тексту й читача, який може враховувати рекомендації автора або порушувати їх, додаючи нову інформацію у процесі інтерпретації. Л. Петрова небезпідставно зауважує, що «художній текст зрозумілий для реципієнта лише в разі збігу концептуальних систем автора та сприймача» (45). Інакше кажучи, дискурсивна діяльність читача актуалізує авторські наміри, проте нерідко додає й власні.

Подібний підхід до розуміння дискурсу як комунікативної ситуації в сукупності 3 їі складниками демонструє О.Селіванова, яка пропонує комунікативну ситуацію розглядати як тричленний акт: автор (мовець) художній текст - читач (реципієнт) (42). Це означає, що читач обов'язковий складник функціювання художнього твору як компонента акту художньої комунікації. К. Сєдов переконаний, що такий підхід до 
аналізу структури дискурсу (він називає його прагматичним) уможливлює розуміння його як «арени взаємодії учасників мовленнєвого акту: мовця (автора тексту), слухача (адресата тексту) і тієї реальності, що віддзеркалено в тексті» (Седов 30). В українському мовознавстві домінує прагматичне тлумачення дискурсу (і художнього зокрема).

Отже, 3 огляду на прагматичний підхід до розуміння дискурсу вважаємо за доцільне послуговуватись термінологічним поняттям «художній дискурс» на позначення художнього тексту як комунікативного утворення, в якому реалізуються комунікативні наміри мовця.

Оскільки в поліпарадигмальному просторі сучасної лінгвістики особливої актуальності набувають антропозорієнтовані теорії, основою яких $є$ людина, що сприймає й ретранслює мову й мовлення в конкретних соціально-історичних умовах, то в лінгвістичних і психолінгвістичних студіях актуалізувалося поняття «концепт». Концепт став ключовим поняттям i для когнітивної методики, яка витлумачує його як «сформоване у свідомості людини поняття про складники реального й уявного світу, виражене за допомогою мовних одиниць» (Горошкіна 129).

Пошук концепту пов'язаний із розумінням авторського задуму, витлумаченням та інтерпретацією змісту тексту, тому В. Кухаренко (80) підкатегорію концептуальності вважає ядром категорії інформативності в художньому тексті. Цю думку підтримує й А. Загнітко, який переконаний, що будь-який «конкретний характер лінійного твору, його змістовофактуальної інформації автор завжди підпорядковує вираженню основної ідеї твору, для втілення якої й існує сам твір» (152).

Читач, сприймаючи художній текст, декодує спочатку зовнішню форму мовних одиниць, з'ясовує їхню стилістичну роль у ньому, після чого заглиблюється в авторський задум (відбувається «накладання образу світу читача на модель світу автора» (Форманова 569)), в результаті чого читач виділяє концепти й визначає їхню функцію в його розкритті.

Водночас лінгвістичний аналіз художнього тексту спрямований на виявлення його стильових домінант. Так, з-поміж засадничих принципів текстової організації українського художнього постмодерністського дискурсу науковці виокремлюють лінгвостилістичні засоби карнавалізації, діалогічної взаємодії з читачем, а також мовної гри. Окремі реалізації останньої фіксуються передусім на лексичному рівні як каламбури (поєднання слів на підставі формальних або семантичних ознак), наприклад: «..вони уже йшли Ринком шукати своє шаманське шампанське...» (Ю. Андрухович. Рекреації); «Тобто створює ілюзію ілюзорності» (Ю. Іздрик. Таке); «Ожив наш край, відпочиваючи від татарсько-московських набегов...» (Б. Жолдак. Антисуржик); «Франциск вважав себе людиною поверхневою. Любив поверхні» (Т. Прохасько. Непрості). Експресивну функцію у «художньому дискурсі некласичної парадигми» (Кондратенко) виконує полістилістичність (поєднання різних стилістичних елементів або фрагментів тексту), яку нерідко презентує 
суржик, наприклад.: «Бо він був начитаний таких книжок, яких я лічно бачив. Такі вони були умні, що навіть переписані ним целіком і полностью вручну» (Б. Жолдак. Райський сад).

Набувають актуальності у сучасному мовознавстві й дослідження, спрямовані на вивчення природи художнього тексту як мовленнєвого утворення, яке репрезентує мовну картину світу його автора. Оскільки кожна людина по-своєму відтворює світ, то І. Живіцька переконана, що мовна картина світу - «суб'єктивний образ об'єктивної реальності, яка сприймається свідомістю» (Живіцька 21). Докладно проаналізувавши праці В. Гумбольдта, Л. Вайсгербера, Е. Сепіра, Б. Уорфа, О. Потебні, В. Жайворонка, В. Ужченка, І. Голубовської, О. Селіванової та ін., дослідниця поділяє думку В. Постовалової, яка вважає, що картина світу не «дзеркальне відображення світу і не відкрите «вікно» у світ, а саме картина, тобто інтерпретація, акт світорозуміння ... вона залежить від призми, через яку здійснюється світобачення» (Постовалова 24).

Як бачимо, лінгвістичний аналіз художнього твору передбачає характеристику не лише мовних, а й позамовних чинників, а також встановлення єдності між його змістом і формою. Нам імпонує думка української дослідниці Р. Зорівчак, яка наполягає, що змістову структуру тексту доречно розглядати у трьох вимірах - вертикальному (формальнотематичний зміст тексту), горизонтальному (оформлення цілісності тексту, створеній формальними й смисловими зв'язками між висловлюваннями) та глибинному (імпліцитний контекст, який увиразнює авторський задум) (Зорівчак). Чимало параметрів художнього тексту репрезентовано імпліцитно (підтекст, концептуально-змістова інформація). Наприклад, пейзаж у художньому тексті - це нерідко не лише тло, на якому відбуваються події, а й засіб розкриття прихованого контексту. Так, опис весни (на тлі тяжкої праці заробітчан) на початку оповідання М. Коцюбинського «По-людському» і поетичний її опис у кінці твору з глибоким риторичним питанням («Чи скоро ми діждемо гармонії й в людському житті?») - це ключ до декодування глибинної структури всього тексту, важлива художня деталь, що поглиблює його вертикальну структуру.

Будь-який людський досвід, за Г. Гадамером, пов'язаний із мовою, опосередкований нею, тому відношення між мовним вираженням i позамовною реальністю є одним із визначальних при осягненні смислу і значень текстових одиниць. Інтерпретація в такій дослідницькій мотивації, на думку О. Луценко, завжди $є$ спробою відтворення певного духовного досвіду з урахуванням історичних та соціальних умов «життя» текстів. Тому під час виконання лінгвістичного аналізу художнього тексту важливо продемонструвати, як у ньому репрезентовані особливості історії, культурні цінності, психоповедінкові архетипи носіїв мови (на рівні лексики, граматики та ін.). Оскільки існують передумови дослідження мови як етнічного явища, то в науці виник термін «етнолінгвістичний 
аналіз тексту», який передбачає виявлення й опрацювання мовних одиниць на позначення культурних та психологічних особливостей етносу.

Як влучно зауважує Н.Лисенко, «слово завжди діалогічне, спрямоване на іншого, щоб бути почутим i зрозумілим, i діалог цей нескінченний і невичерпний» (333). Н. Кондратенко ж, аналізуючи особливості синтаксичної організації постмодерністських творів, доводить, що діалогічність художнього мовлення може виражатися як на рівні міжсуб'єктної взаємодії (між автором і читачем), так і на рівні міжтекстової взаємодії (інтертекстуальність). Дослідниця пропонує, крім категорії комунікативності, виокремлювати таку текстову категорію, як інформативність. Щодо останньої, то її наявність І. Кочан пов’язує із новою інформацією та «ступенем її новизни і несподіваності» (42).

Здійснений аналіз наукової літератури з теми дослідження дозволяє стверджувати, що художня творчість - це складний комунікативний процес, який є реалізацією певного комунікативного наміру автора щодо реципієнта. Під час породження художнього тексту його автор моделює комунікативну ситуацію, яку визначають як вербальні, так і невербальні чинники. Вони впливають не лише на створення, а й на розуміння тексту, який є об'єднувальною ланкою комунікативного простору інтерпретації читача й комунікативного простору автора. Проте читач не завжди адекватно інтерпретує прагматичну настанову автора: його дискурсивна діяльність актуалізує авторські наміри, проте може й додавати власні.

Висновки та перспективи досліджень. Отже, художнє мовлення це об'єкт лінгвістичних досліджень у межах двох мовознавчих парадигм традиційної (системоцентричної), зосередженої на вивченні мовних одиниць і на лінгвостилістичній специфіці художнього мовлення окремих авторів, та сучасної (прагматично-комунікативної), зорієнтованої на комунікативній ситуації та її складниках. Дискурсивний статус художнього тексту актуалізує прагматичний чинник у ньому, що уможливлює інтерпретацію художнього тексту не лише як фіксацію повідомлення в комунікативному акті, а й акцентує увагу на комунікативних ролях автора й читача. Це означає, що художній текст - лише один із компонентів художньої комунікації, яку, крім того, формують дискурси автора та читача, збіг концептуальних систем яких $\epsilon$ обов'язковою умовою для адекватного розуміння художнього тексту.

\section{Список використаної літератури}

Бабенко, Людмила, и Казарин, Юрий. Лингвистический анализ художественного текста. Теория и практика. Москва: Флинта, Наука, 2003.

Воробьева, Ольга. Лингвистические аспекты адресованности художественного текста (одноязычная и межъязыковая коммуникации). Автореф. дисс. ...докт. филол. наук : спец. 10.02.19. Москва, 1993.

Гадамер, Ханс-Георг. Истина и метод. Основы философской герменевтики. Перевод Б. Н. Бессонова. Москва: Прогресс, 1988. 
Горошкіна, Олена. «Роль когнітивної методики у формуванні соціокультурної компетенції учнів». Семантика мови і тексту: матеріали ХІ Міжнародної наукової конференції. Івано-Франківськ, 2012, с. 127-30.

Живіцька, Інна. «Мовна картина світу як відображення реальності». Філологічні студії: Науковий вісник Криворізького державного педагогічного університету, вип. 4, 2010, c. 20-5.

Загнітко, Анатолій. Лінгвістика тексту: теорія і практикум. Донецьк: Юго-Восток, 2007.

Зорівчак, Роксоляна. Реалія і переклад (на матеріалі англомовних перекладів украӥнської прози). Львів, 1989.

Єрмоленко, Світлана. «Стилістика сучасної української літературної мови в контексті слов'янських стилістик». Мовознавство, № 2-3, 1998, с. 25-36.

Ковалик, Іван. Методика лінгвістичного аналізу тексту. Київ: Вища школа, 1984.

Колегаева, Ирина. Текст как единица научной и художественной коммуникации. Одесса, 1991.

Кондратенко, Наталія. Синтаксис украӥнського модерністського і постмодерністського художнього дискурсу. Київ, 2012.

Кочан, Ірина. Лінгвістичний аналіз тексту. 2-ге вид. Київ: Знання, 2008.

Кулибина, Наталья. Художественный дискурс как актуализация художественного текста в сознании читателя. URL: http://www.gramota.ru/biblio/magazines/mrs/ mrs2001-01/28_211.

Кухаренко, Валерія. Інтерпретація тексту. Вінниця: Нова книга, 2004.

Лисенко, Неля. «Специфіка художнього слова і його функціональні вияви в українській літературі». Рідне слово в етнокультурному вимірі. Дрогобич: Посвіт, 2012.

Луценко, Оксана. «Герменевтичні критерії лінгвістичного аналізу тексту». Актуальні проблеми сучасної філологї. Мовознавчі студї̈, вип. 21 (3), 2013, с. 131-3.

Михайлов, Н. Теория художественного текста. Москва: Издательский центр «Академия», 2006.

Папина, Аза. Текст: его единицы и глобальные категории. Москва, 2002.

Петрова, Л. Лингвокогнитивные основы художественной картины мира. Симферополь, 2006.

Плеханова Т. Дискурс-анализ текста. Минск: ТетраСистемс, 2011.

Постовалова, Валентина. Картина мира в жизнедеятельности человека. Роль человеческого фактора в языке: язык и картина мира. Москва: Наука, 1988.

Прохоров, Юрий. Действительность. Текст. Дискурс. Москва: Флинта; Наука, 2006.

Седов, Константин. Дискурс и личность: эволюция коммуникативной компетенции. Москва: Лабиринт, 2004.

Селиванова, Елена. Основы лингвистической теории текста и коммуникации. Киев: ЦУЛ; Фитосоциоцентр, 2002.

Селіванова, Олена. Сучасна лінгвістика: напрями та проблеми. Полтава: Довкілля-К, 2008.

Сидоров, Евгений. Онтология дискурса. 2-е изд. Москва, 2009.

Форманова, С. «Функціонально-стилістична семантика заголовка як структуроутворюючого елемента тексту». Вісник Прикарпатського національного університету ім. В. Стефаника. Філологія, вип. XV-XVIII, 2007, с. 566-70. 


\section{References}

Babenko, Ljudmila, and Kazarin, Jurij. Lingvisticheskij analiz hudozhestvennogo teksta. Teorija $i$ praktika. Moskva: Flinta, Nauka, 2003.

Vorob'eva, Ol'ga. Lingvisticheskie aspekty adresovannosti hudozhestvennogo teksta (odnojazychnaja i mezhjazykovaja kommunikacii). Doctoral Thesis Abstract. Moskva, 1993.

Gadamer, Hans-Georg. Truth and Method, edited by B. N. Bessonov. Moskva: Progress, 1988.

Horoshkina, Olena. "Rol kohnityvnoi metodyky u formuvanni sotsiokulturnoi kompetentsii uchniv". Semantyka movy i tekstu: materialy XI Mizhnarodnoi naukovoi konferentsii. Ivano-Frankivsk, 2012, pp. 127-30.

Zhyvytska, Inna. "The language picture of the world as a reflection of the reality". Philological Studies. Scientific bulletin of Kryvyi Rih State Pedagogical University, iss. 4, 2010, pp. 20-5.

Zahnitko, Anatolii. Linhvistyka tekstu: teoriia i praktykum. Donetsk: Yuho-Vostok, 2007.

Zorivchak, Roksoliana. Realiia i pereklad (na materiali anhlomovnykh perekladiv ukrainskoi prozy). Lviv, 1989.

Yermolenko, Svitlana. "Stylistyka suchasnoi ukrainskoi literaturnoi movy v konteksti slovianskykh stylistyk". Movoznavstvo, no 2-3, 1998, pp. 25-36.

Kovalyk, Ivan. Metodyka linhvistychnoho analizu tekstu. Kyiv: Vyshcha shkola, 1984.

Kolegaeva, Irina. Tekst kak edinica nauchnoj i hudozhestvennoj kommunikacii. Odessa, 1991.

Kondratenko, Nataliia. Syntaksys ukrainskoho modernistskoho i postmodernistskoho khudozhnoho dyskursu. Kyiv, 2012.

Kochan, Iryna. Linhvistychnyi analiz tekstu. 2nd ed. Kyiv: Znannia, 2008.

Kulibina, Natal'ja. Hudozhestvennyj diskurs kak aktualizacija hudozhestvennogo teksta $v$ soznanii chitatelja. www.gramota.ru/biblio/magazines/mrs/mrs2001-01/28_211

Kukharenko, Valeriia. Interpretatsiia tekstu. Vinnytsia: Nova knyha, 2004.

Lysenko, Nelia. "Spetsyfika khudozhnoho slova i yoho funktsionalni vyiavy v ukrainskii literaturi". Ridne slovo v etnokulturnomu vymiri. Drohobych: Posvit, 2012.

Lutsenko, Oksana. "Hermenevtychni kryterii linhvistychnoho analizu tekstu". Aktualni problemy suchasnoi filolohii. Movoznavchi studii, iss. 21 (3), 2013, pp. 131-3.

Mihajlov, N. Teorija hudozhestvennogo teksta. Moskva: Izdatel'skij centr "Akademija", 2006.

Papina, Aza. Tekst: ego edinicy i global'nye kategorii. Moskva, 2002.

Petrova, L. Lingvokognitivnye osnovy hudozhestvennoj kartiny mira. Simferopol', 2006.

Plehanova T. Diskurs-analiz teksta. Minsk: TetraSistems, 2011.

Postovalova, Valentina. Kartina mira v zhiznedejatel'nosti cheloveka. Rol' chelovecheskogo faktora v jazyke: jazyk i kartina mira. Moskva: Nauka, 1988.

Prohorov, Jurij. Dejstvitel'nost'. Tekst. Diskurs. Moskva: Flinta; Nauka, 2006.

Sedov, Konstantin. Diskurs i lichnost': jevoljucija kommunikativnoj kompetencii. Moskva: Labirint, 2004.

Selivanova, Elena. Osnovy lingvisticheskoj teorii teksta i kommunikacii. Kiev: CUL; Fitosociocentr, 2002.

Selivanova, Olena. Suchasna linhvistyka: napriamy ta problemy. Poltava: Dovkillia-K, 2008.

Sidorov, Evgenij. Ontologija diskursa. $2^{\text {nd }}$ ed. Moskva, 2009.

Formanova, S. "Funktsionalno-stylistychna semantyka zaholovka yak strukturoutvoriuiuchoho elementa tekstu". Newsletter of Precarpathian University. Philology, iss. XV-XVIII, 2007, pp. 566-70. 